\title{
REASONS TO DEVELOPMENT OF ASSISTANT PHARMACISTS' COMPETENCES FOR QUALITY PATIENT CONSULTING IN POLYPHARMACY CASES
}

\author{
Elita Ardava \\ RSU Red Cross Medical College, Latvia \\ Valerija Makšāne \\ RSU Red Cross Medical College, Latvia \\ Renāte Šukele \\ RSU Red Cross Medical College, Latvia \\ Oskars Onževs \\ Turība University, Latvia
}

\begin{abstract}
Over fifteen years, polypharmacy has increased by $4.9 \%$ across all age groups. Consequently, the responsibility of professionals for advising patients in such cases has increased as well. The research aims at studying patients' habits when purchasing and using medicinal products to enhance the theoretical and practical training of assistant pharmacists at the RSU Red Cross Medical College. The research is based on the patient questionnaires and further analysis of results within a focus group. 404 respondents were interviewed between December 2017 and November 2019. Under the conventions of social studies, this ensured a $3 \%$ margin of error at a confidence level of 5\%. According to the results of the questionnaire, $44 \%$ of the surveyed women and $66 \%$ of men were rarely or very rarely interested in the possible side effects of a new medicinal products, food supplement or herbal product. Patients could obtain such information by reading the package leaflet, however, $24 \%$ of women and $40 \%$ of men read it very rarely or rarely. $30 \%$ of respondents used four or more prescription and over-the-counter medical substances on a daily basis. The information-gaining habits of the population regarding side effects and interactions of medicinal products, food supplements and herbal remedies suggest patients must receive oral and more detailed information from a pharmacist. Based on the obtained results, the focus group outlined opportunities for raising pharmacy students' competences.
\end{abstract}

Keywords: irrational use of medicinal products, polypharmacy, risks of medication use.

\section{Introduction}

The study deals with the prevalence of polypharmacy in Latvia and searches for the ways to reduce the various risks facing such patients. One of the ways how to achieve the goal is by partly changing the content of the study programmes thus 
Ardava et al., 2020. Reasons to Development of Assistant Pharmacists'Competences for Quality Patient Consulting in Polypharmacy Cases

providing higher quality training of professionals who will work under the conditions of increasing polypharmacy.

In the study of the National Center for Biotechnology Information (NBCI) it was found that polypharmacy had increased by $4.9 \%$ in all age groups over the last fifteen years (Oktora et al., 2019).

Nowadays, the rise of polypharmacy is attributable also to the increased human life expectancy and, consequently, to the presence of more comorbidities in a person. Such illnesses can be better treated by administering several medicinal products simultaneously, which increases the risk of adverse drug reactions and other hazards related to the use of medicinal products.

The study conducted by Marshall University School of Pharmacy (USA, 2015) examined the possible consequences of polypharmacy, which represent the following:

1. High healthcare costs to patients, insurance providers and public.

2. Lack of knowledge about the medicinal products in patients and their noncompliance to the use of the medicinal products.

3. Drug-drug interactions.

4. Risk of possible adverse reactions.

5. Risk of falling.

6. Poor quality of life (functional condition).

7. Increased risk of medication errors (Gillette et al., 2015).

The global experience in cases of polypharmacy suggested that it is necessary to study the situation among the pharmacy customers in Latvia.

Thus, the aim established for the study was to explore the patients' habits in acquiring and using medicinal products and relate them to the opportunities for theoretical and practical training of assistant pharmacists at the RSU Red Cross Medical College.

\section{Materials and Methods}

The authors analysed the statistics for years 2013 to 2018 derived from the data of the State Agency of Medicines on the trade of medicinal products and the average price of a package. The data were related to the size of population in Latvia in the same period.

During the research the survey of the pharmacy visitors was conducted with the participation of 404 respondents above 20 years of age. The survey comprised the respondents who voluntarily agreed to complete the questionnaire. The participants could ask for consultations on the questions included in the questionnaire, if they needed any. The study was performed from December, 2017 to November, 2019 in various cultural and historic regions of Latvia. The survey was conducted in the framework of the RSU Red Cross Medical College research 
project, and a questionnaire was designed for it in Latvian and comprised 18 questions. Besides, there also were two questions to summarize the results, which were completed by the researchers themselves. In this article we only used only part of data collected to analyse and describe.

The scientific articles used in the study were found in PubMed and Google Scholar data bases and account for period 2009 to 2019.

After completion of the survey, 8 members of the focus group were introduced to the statistical data analysis and the results acquired by analysing the survey. After that there was time allocated and 6 questions posed, which the focus group had to answer in writing. This was followed by a discussion of the questions in the group, which led to the opinion expressed by the majority of the participants on how to improve the acquisition of competences at the RSU Red Cross Medical College under the given conditions. Among the participants of the focus group there were 2 representatives of employers, pharmacists by education, as well as 6 faculty members of Rīga Stradiņš University and RSU Red Cross Medical College.

\section{Results}

\section{Analysis of changes in the size of population and consumption of medicinal products over six years}

The authors examined the dynamics of changes in the size of population and costs of medicinal products in the country in the period between 2013 and 2018. The size of population has been steadily decreasing from 2,001,468 people in 2013 to 1,919,968 people in 2018. At the same time, the average consumption of medicinal products has increased from 432.81 MM EUR to 568.58 MM EUR in the respective period. The absolute basic growth of the consumption of medicinal products in 2018 compared to 2013 accounted for 79.89 EUR per person. The average expenses per person had increased from 216.25 EUR in 2013 to 296.14 EUR in 2018. In Figure 1, it is shown as the growth rate base compared to 2013. It can be seen that the consumption of medicinal products has been rising rapidly.

Besides the medicinal products, residents also use food supplements and other pharmaceutical goods, which are not provided under a separate section in statistics. Their turnover has increased from 41.89 MM EUR to 61.61 MM EUR and the growth accounts for 19.72 MM EUR. (Oktora et al., 2019; Centrālā statistikas pārvalde $(2013,2015,2016,2019)$ Zāḷ valsts aǵentūra $(2017,2018$, 2019a, 2019b)) This shows amounts of information necessary to provide high quality consultation in pharmacies. 
Ardava et al., 2020. Reasons to Development of Assistant Pharmacists'Competences for Quality Patient Consulting in Polypharmacy Cases

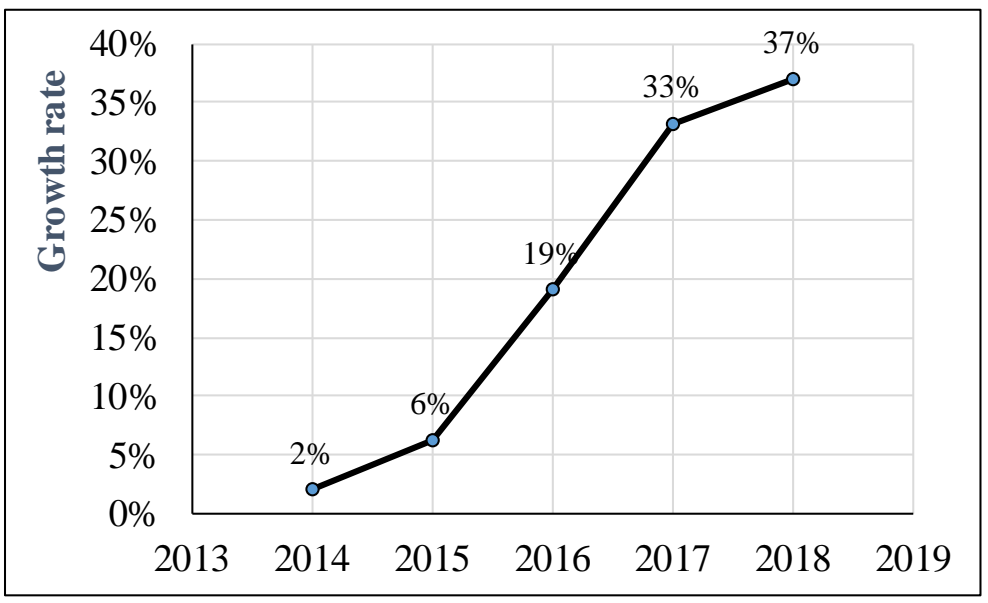

Figure 1 Growth rate of drug base compared to 2013

Besides the medicinal products and food supplements purchased in pharmacies, the residents also use herbal teas they have acquired elsewhere or collected themselves. The authors could not analyse the turnover data on food supplements as they are not distinguished from other pharmaceutical goods in the annual reports of the State Agency of Medicines.

Patients' habits regarding purchasing medicinal products in pharmacies

$31 \%$ of the surveyed respondents simultaneously used 4 to 10 prescription and over-the-counter active substances, which corresponds to the approved polypharmacy definitions (see table 1). Globally, the term "polypharmacy" has several explanations, however mostly it accounts for simultaneous use of 4 to 5 or more medicinal products.

Table 1 Concomitant use of prescription and non-prescription drug active substances (number of active substances and proportion of users)

\begin{tabular}{|l|c|c|c|c|c|c|c|c|c|}
\hline $\begin{array}{l}\text { Number of active } \\
\text { substances used }\end{array}$ & None & 1 & 2 & 3 & 4 & 5 & 6 & 7 & $>8$ \\
\hline $\begin{array}{l}\text { Proportion of } \\
\text { users }\end{array}$ & $10.1 \%$ & $16.8 \%$ & $26.2 \%$ & $16.8 \%$ & $14.1 \%$ & $6.7 \%$ & $2.5 \%$ & $4.2 \%$ & $2.4 \%$ \\
\hline
\end{tabular}

A meta-analysis has been performed in the world and information collected by "Medline", "Embase" and "Cochrane" to find the articles mentioning the definition of polypharmacy. The publications were selected in the period from January, 2000 to May, 2016. Polypharmacy was defined in 138 articles out of 1156 selected studies. In a part of the definitions $(46.4 \%$ of the selected publications), the polypharmacy was mentioned as a simultaneous use of five or more medicinal products per day. In some polypharmacy definitions the number accounted for the simultaneous use of two to eleven medicinal products. $6.4 \%$ of 
the definitions mentioned therapeutic and problematic polypharmacy (Masnoon et al., 2017).

Therapeutic polypharmacy implies the cases when several medicinal products are simultaneously used for the treatment of several diseases. Problematic polypharmacy, however, describes the cases when medicinal products are prescribed inappropriately and the desired effect is absent (Duerden \& Payne, 2014).

Along with the prescription and over-the-counter medicinal products people also use food supplements, in which the manufacturers have combined various vitamins, minerals and herbal extracts in smaller dosages, however larger number. In the study, $48 \%$ of the 404 respondents periodically used the active substances of 5-10 food supplements (see Figure 3). The courses of food supplements may be taken twice a year once for 2 to 3 months. People also use food supplements seasonally, for example, vitamin D3 is more often used in autumn, winter and spring. There were cases when as many as 38 active substances were used simultaneously. Apart from the term "polypharmacy", there is another globally known term describing the ingestion of herbal products or "polyherbacy". They are not registered as medicinal products, but rather as food products, which relieves their distribution. In Latvia, we call them food supplements and they are available both in pharmacies and supermarkets, as well as online, consequently, the availability of such products is considerably big. The information on food supplements can be acquired in different ways, however it is not always reliable. As it was found, 55\% of women and 32\% of men read the necessary information about the products. These products may have therapeutic potential, however, they should be used under a health care professional`s supervision. In the study hereby, it was found that $48 \%$ of the respondents face a substantial risk as they tend to follow their own initiative when starting to use these products. These patients are under the risk of drug-drug interaction. The risk is higher in people who simultaneously use both prescription and over-the-counter medicinal products. The risk is particularly high in elderly people whose body has undergone physiological changes, e.g. kidney and liver detoxication and clearance, which usually decreases with age (Gonzalez-Stuart, 2011).

The use of various herbal products is taken up both following a doctor's recommendation (27\% of cases), when a professional already partly sees the complete picture regarding the medicinal products used by the patient. However, in $18 \%$ of cases the products have been recommended to the patient by a pharmacist or assistant pharmacist, which means that the respective professionals have to be more involved in a proper consulting of the patient. In $48 \%$ of cases patients start using herbal products following their own initiative, which can represent the highest risk (see Figure 2). Study shows that reasons to use herbal medicine are lack of effectiveness and side effects of conventional drugs, 
Ardava et al., 2020. Reasons to Development of Assistant Pharmacists'Competences for Quality Patient Consulting in Polypharmacy Cases

disappointment in therapy. Mostly people search for information in books and journals, consult with family more often than with healthcare providers. People rarely seek information about medicinal plant side effects. Reason is belief that herbal medicine is less harmful, because they have been used for generations and are known by names and even grown in their own gardens (Welz et al., 2018). Lynch \& Berry (2007) note that people consider herbal medicine safer than OTC and are less likely to consult doctor prior using them. Self - prescribing of medicinal plants is very common among cancer patients, and is not monitored by their oncologist. After consulting with health care provider (HCP) $15.3 \%$ of herbal medicine users had to stop taking them due to safety concerns (Samuels et al., 2017). This raises concerns about safe herbal medicine use and shows that similar problems are discovered in many studies.

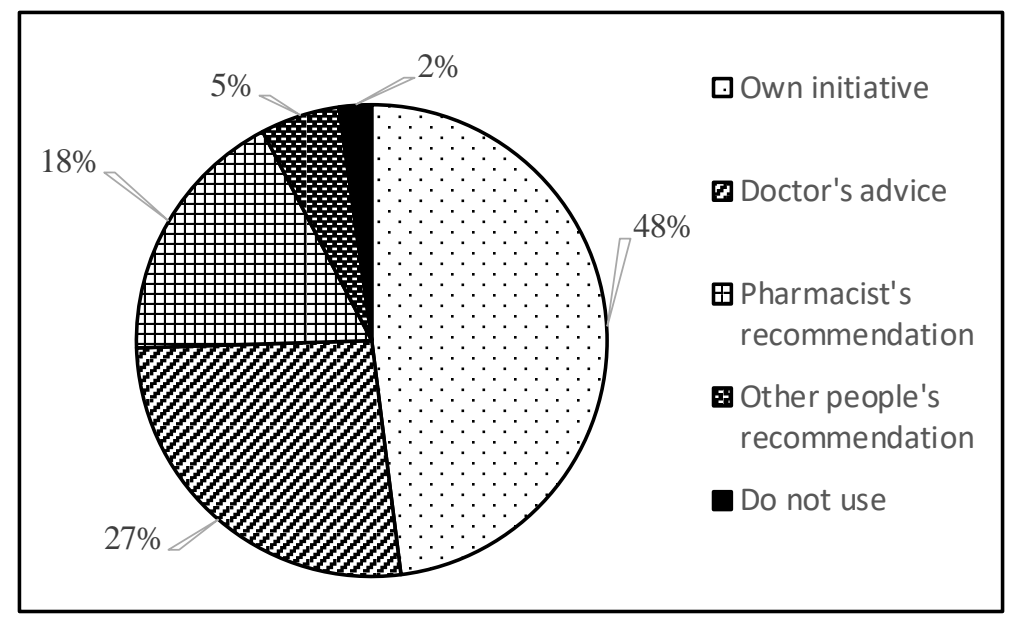

Figure 2 Initiators for the beginning of using herbal preparations

Figure 3 shows how often women and men get acquainted with the side effects and possible allergic reactions to a new food supplement or herbal product. 169 women or $55 \%$ of all female respondents searched such information rather often, often, very often or always. From the 95 men who were surveyed 30 respondents had searched for it, which accounts for 32\%. As the figure shows, women do both - they use such products more often and also search information on them more often. Similar findings were described by Leemans et al. (2011). 


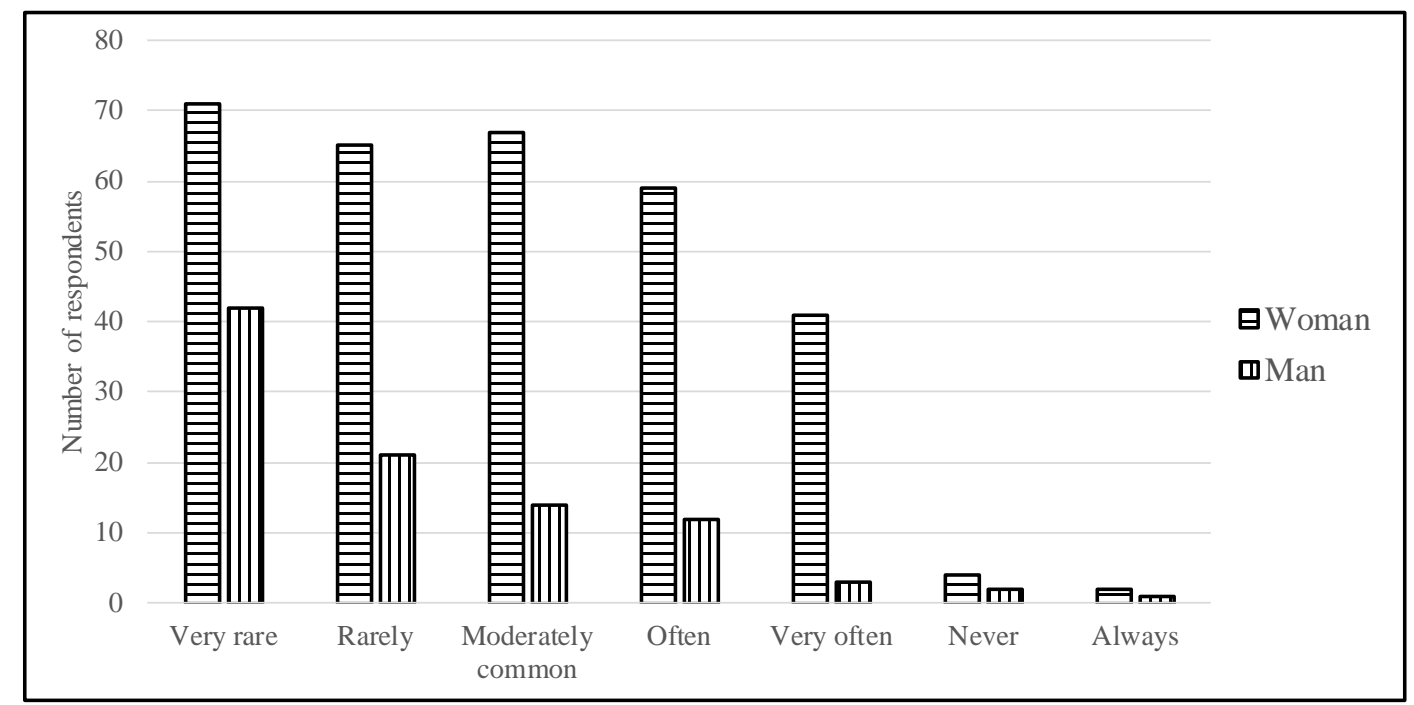

Figure 3 Familiarization of possible side effects and allergic reactions

Although, herbal medicine side effects were reported by 25\% of herbal medicine user. Most of respondents did not inform practitioner about use of herbal medicine and HCP did not ask, as they lack knowledge about medicinal plants (Fathy et al., 2019). On the account of men being less inclined to search for information HCP should be more proactive in consulting them about safe use of medicine.

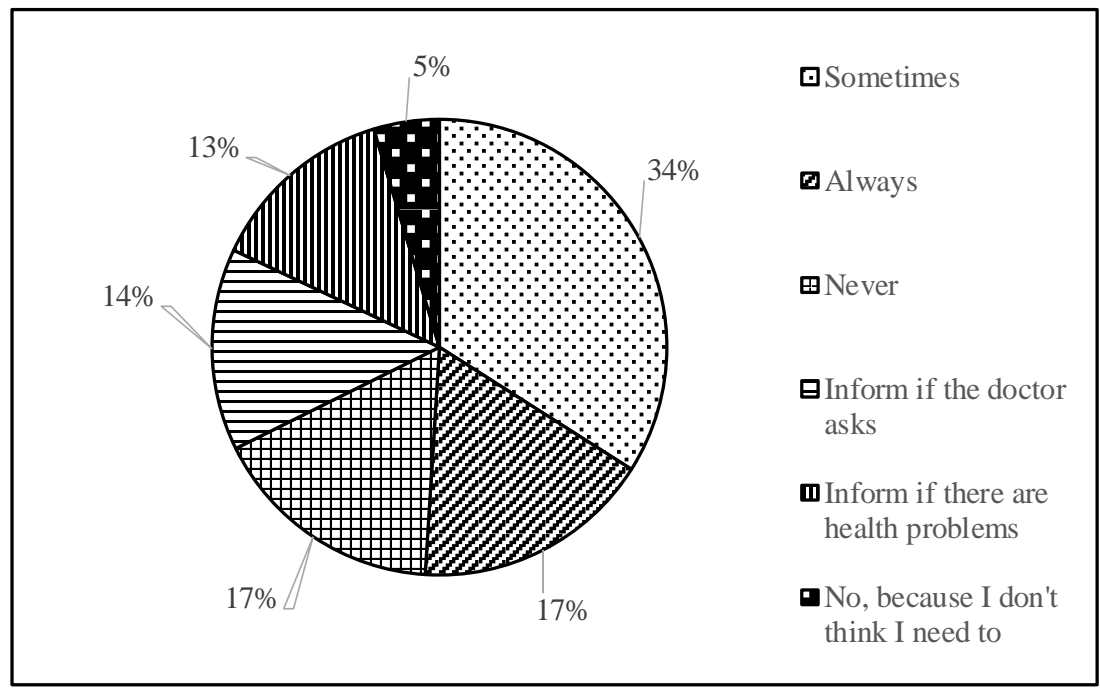

Figure 4 Informing physicians of all prescription medications and over-the-counter medications, supplements, and herbs used

To provide for the safety of using simultaneously prescription and over-thecounter medicinal products together with food supplements the primary care physician or a specialist must be informed about it. As we see in Figure 4, 34\% 
of the respondents always provide a specialist with such information. The ones who sometimes inform a specialist account for $17 \%$ and the same number of respondents never inform a doctor, $14 \%$ answer, if the doctor asks. 5\%, however, consider it unnecessary.

Review about patient consultations about herbal medicine with healthcare providers showed that about one third disclosed to practitioner herbs used. Additionally, doctors were not active in asking questions about alternative medicines used during consultation (Enioutina et al., 2016). Our study suggests that $14 \%$ of the respondents have experienced problems in using medicinal products and informed the doctor afterwards. However, to obtain more reliable information on simultaneous consumption of food supplements together with medicinal products, not only doctors, but also pharmacists and assistant pharmacists can be asked.

\section{Analysis of the study results in the focus group}

The experts, after acquainting themselves with the analysis of the statistical data and the results of the survey data analysis, saw that the use of many medicinal products is also characteristic to the inhabitants of Latvia. In $49 \%$ of cases, patients do not inform their doctor about the use of over-the-counter medicinal products, food supplements and herbal products along with prescription medicinal products or inform the doctor about it only when they are asked. Under such a situation much more responsibility should be assumed by pharmacists and assistant pharmacists, who are the ones who issue medicinal products to the patients. Studies show that HCP education should include topics about herbal medicine and other complementary and alternative therapies use and safety concerns. Although pharmacists have good knowledge about medicinal plants, continuous education should provide more information about herbal medicine interactions with OTC and prescription medicine and patient consultation (Alsayari et al., 2018; Boesl \& Saarinen, 2016; Enioutina et al., 2016; Taing et al., 2016) Consequently, the future assistant pharmacists should develop their competences at higher level in the following areas:

1) To find out more specifically the patient's situation in using over-thecounter medicinal products, food supplements and herbal products during the purchase as they can be used simultaneously with prescription medicinal products.

2) Based on the acquired information, to provide further information on drug-drug interactions.

3) To provide information on the most common adverse drug reactions as their risk increases if more active substances are used concomitantly. 
4) To provide information on the possibilities to reduce the expressions of adverse drug reactions, if any.

5) To inform the patients about the possible contraindications or caution in simultaneous use of prescription and over-the-counter medicinal products, if it can decrease the effect of the patient's prescription medicinal products.

The focus group suggested creating a new study course "Adverse drug reactions and interactions" for higher quality training of the students for such consultations.

\section{Conclusions}

The analysis of the statistical data shows the steadily rising consumption of medicinal products per capita in Latvia. The research proves that the usage of medicinal products, food supplements and herbal products is widespread among the Latvian population. One-third of the respondents visiting pharmacies use 4 to 10 medical substances, which corresponds to the globally accepted polypharmacy definition. This increases the risk of drug-drug interaction and increases the likelihood of adverse drug reactions. In order to raise the customer awareness about the possible risks of using medicinal products and food supplements it is also necessary to improve the training of pharmacy professionals. It could be facilitated by the suggestions put forward by the focus group participants: to acquire more detailed information from the patients on their usage of medicinal products and provide them with more detailed instructions on the use of medicinal products, food supplements and herbal products.

\section{Acknowledgements}

Survey was done within the RSU Red Cross Medicine college research project "Medicine, food supplements and herbal medicine use in Latvia and associated risks for patients” Nr.2-30/2017/069

\section{References}

Alsayari, A., Almghaslah, D., Khaled, A., Annadurai, S., Alkhairy, M.A., Alqahtani, H.A., ... \& Assiri, A.M. (2018). Community Pharmacists’ Knowledge, Attitudes, and Practice of Herbal Medicines in Asir Region, Kingdom of Saudi Arabia. Evidence-Based Complementary and Alternative Medicine. Retrieved from DOI: https://doi.org/10.1155/ 2018/1568139

Boesl, R., \& Saarinen, H. (2016). Essential Oil Education for Health Care Providers. Integrative medicine (Encinitas, Calif.), 15(6), 38-40. 
Ardava et al., 2020. Reasons to Development of Assistant Pharmacists'Competences for Quality Patient Consulting in Polypharmacy Cases

Centrālās statistikas pārvalde. (2013). Iedzīvotāju skaits samazinās zem divu miljonu robežas, Preses relize. Pieejams https://www.csb.gov.lv/lv/statistika/statistikas-temas/iedzivotaji/ iedzivotaju-skaits/meklet-tema/1588-par-iedzivotaju-skaita-izmainam-2013gada

Centrālās statistikas pārvalde. (2015). 2015. gada sākumā Latvijā par 15,4 tūkstošiem iedzīvotāju mazāk. Preses relīze. Pieejams https://www.csb.gov.lv/lv/statistika/ statistikas-temas/iedzivotaji/iedzivotaju-skaits/meklet-tema/1736-par-iedzivotaju-skaitaizmainam-latvija

Centrālās statistikas pārvalde. (2016). 2016. gada sākumā Latvijā par 17,1 tūkstoti iedzīvotāju mazāk nekā pirms gada. Preses relīze. Pieejams https://www.csb.gov.lv/lv/statistika/ statistikas-temas/iedzivotaji/iedzivotaju-skaits/meklet-tema/1983-iedzivotaju-skaitaizmainas-latvija-2015 (2015)

Centrālās statistikas pārvalde. (2019). Latvijā krītas dzimstība un turpina samazināties migrācija. Preses relīze. Pieejams https://www.csb.gov.lv/lv/statistika/statistikastemas/iedzivotaji/iedzivotaju-skaits/meklet-tema/2444-iedzivotaju-skaita-izmainaslatvija-2018

Duerden, M., \& Payne, R. (2014). Polypharmacy - what is it and how common is it? Prescriber, 25, 44-47. DOI: 10.1002/psb.1274

Enioutina, E.Y., Salis, E.R., Job, K.M., Gubarev, M.I., Krepkova, L.V., \& Sherwin, C.M. (2017). Herbal Medicines: challenges in the modern world. Part 5. status and current directions of complementary and alternative herbal medicine worldwide. Expert review of clinical pharmacology, 10(3), 327-338.

Fathy, H., El-Hawy, R., \& Hassan, R. (2019). Attitudes, Knowledge and Practice of Herbal Remedy Use among the Population Visiting Pharmacies and Health Care Providers in Alexandria, Egypt: A Cross-Sectional Study. European Journal of Medicinal Plants, 30(2), 1-10.

Gillette, C., Prunty, L., Wolcott, J., Broedel-Zaugg, K. (2015). A new lexicon for polypharmacy: implications for research, practice, and education. Research in Social and Administrative Pharmacy, 11(3), 468-471. DOI: 10.1016/j.sapharm.2014.08.010.

González-Stuart, A. (2011). Herbal product use by older adults. Maturitas, 68(1), 52-55. DOI: https://doi.org/10.1016/j.maturitas.2010.09.006

Leemans, L., Heylen, N., Quanten, A., \& Deferme, S. (2011). Consumer study on the use of patient information leaflets. Journal de pharmacie de Belgique, 4, 109-116.

Lynch, N., \& Berry, D. (2007). Differences in perceived risks and benefits of herbal, over-thecounter conventional, and prescribed conventional, medicines, and the implications of this for the safe and effective use of herbal products. Complementary therapies in medicine, 15(2), 84-91.

Masnoon, N., Shakib, S., Kalisch-Ellett, L., \& Caughey, G. E. (2017). What is polypharmacy? A systematic review of definitions. BMC geriatrics, 17(1), 230.

Oktora, M.P., Denig, P., Bos, J.H., Schuiling-Veninga, C.C., \& Hak, E. (2019). Trends in polypharmacy and dispensed drugs among adults in the Netherlands as compared to the United States. PloS one, 14(3).

Samuels, N., Ben-Arye, E., Maimon, Y., \& Berger, R. (2017). Unmonitored use of herbal medicine by patients with breast cancer: reframing expectations. Journal of cancer research and clinical oncology, 143(11), 2267-2273.

Taing, M.W., Tan, E.T.X., Williams, G.M., Clavarino, A.M., \& McGuire, T.M. (2016). Herbal and nutrient complementary medicines for weight loss: community pharmacists' practices, attitudes, recommendations, information and education needs. International Journal of Pharmacy Practice, 24(3), 160-169. 
Welz, A.N., Emberger-Klein, A., \& Menrad, K. (2018). Why people use herbal medicine: insights from a focus-group study in Germany. BMC complementary and alternative medicine, 18(1), 92.

Zāḷ̆u valsts aǵentūra. (2017). Zāạlu patêriṇa statistika 2016. Sagatavoja/ Prepared by: A. Seilis, A. Zaḳe, E. Gailīte Izdevējs/ Publisher: Zāḷ valsts ağentūra/ State Agency of Medicines. Pieejams https://www.zva.gov.lv/sites/default/files/2017-12/zva-zstat-2016.pdf

Zāḷ valsts aǵentūra. (2018). Zālu patêriṇa statistika 2017. Sagatavoja/ Prepared by: A. Seilis, E. Gailīte Izdevējs/ Publisher: Zāḷ valsts ağentūra/ State Agency of Medicines. Pieejams https://www.zva.gov.lv/sites/default/files/2018-05/zva-zstat-2017.pdf

Zāḷ valsts aǵentūra. (2019a). Zālu patêrina statistika 2018. Sagatavoja/ Prepared by: A. Seilis, E. Gailīte Izdevējs/ Publisher: Zāḷu valsts ağentūra/State Agency of Medicines. Pieejams https://www.zva.gov.lv/sites/default/files/2019-06/2018.pdf

Zāḷu valsts aǵentūra. (2019b). Zāḷ tirgus dinamika (miljonos eiro) 2013 - 2018. Pieejams https://www.zva.gov.lv/lv/publikacijas-un-statistika/oficiala-statistika-informacija/zalutirgus-dinamika 